Council for the next three-year period, from January 1972 to December 1974 , and a list is being submitted for the approval of the Governing Body.

Considerable thought was devoted to the consideration of the scope of the Institute's future activities in the light of the great expansion in African studies and the financial problems with which it was being faced. Detailed plans will be prepared for consideration at its next meeting.

The Council welcomed to its closing session a number of Belgian scholars who reported on the aims and achievements of their institutions and informed it of the development of African studies both in Belgium and in Congo (Kinshasa).

\title{
Research Information Liaison Unit: International Information Bulletins
}

THIS series of bulletins will list comprehensively, over a two- to three-year period, all available information on research under way in the organizations listed in the Register of Organisations undertaking Africanist Research (published March I97I). They will include research in archaeology, the arts, history, language studies, law studies, political science, human geography, sociology, social anthropology/ethnography, psychology, and relevant aspects of economics, education, and social administration.

The bulletins will also contain news on the formation of new specialist institutions and centres, on the initiation and progress of large-scale or comparative projects, on the availability of research papers from conferences and seminars, and will, from time to time, include reports on research developments and needs in particular regions or topics.

Every issue of the bulletin will include listing of information received on research in all regions of Africa. The first issue (to appear in November 1971) will, however, contain more detail on Western Africa and the Congo (price $f 4$ ).

Standing orders for these bulletins should be addressed to: The Secretary, International African Institute, ro/ I Fetter Lane, London, $\mathrm{EC}_{4}$ rBJ.

\section{Third Annual Conference on African Linguistics}

The Third Annual Conference on African Linguistics will be held at Indiana University on 7 and 8 April 1972, under the joint sponsorship of the African Studies Program, the Department of Linguistics, and the Research Center for the Language Sciences. Anyone interested in attending or presenting a paper should write to: Third Annual Conference on African Linguistics, Department of Linguistics, Indiana University, Bloomington, Indiana, 4740 r.

\section{The History and Problems of the Interaction of Christian and Traditional Marriage}

IN March I97 I meeting took place in Kampala, Uganda, of a group of scholars concerned with this project which is being co-ordinated by Dr. Aylward Shorter of the Gaba Pastoral Institute, P.O. Box 4165 , Kampala. He writes: 'I am co-ordinating a piece of large-scale research in Eastern, Central and possibly Southern Africa, carried out by the different Christian churches into the history and problems of the interaction of Christian and Traditional Marriage. This research will be part theological, part anthropological. We are being assisted by Notre Dame University.'

\section{African Studies at Howard University}

AT the request of the District of Columbia Board of Education, in 1 969-70, Howard University sponsored an experimental programme in the D.C. senior high schools, introducing Swahili and African history (taught in Swahili), carried out by advanced graduate students from the African Studies Center. The programme is to be repeated this year. 